\title{
The Syariah Courses of Islamic Law of Securities and Islamic Family Law: Revamping the Teaching and Learning Techniques in Ensuring Marketability of UKM's Law Graduates
}

\author{
Ahmad Azam Mohd Shariff1 \\ Nazura Abdul Manap² \\ Asma Hakimah Ab Halim³ \\ Fatimah Yusro Hashim 4 \\ Ramalinggam Rajamanickam ${ }^{5}$ \\ Mohamad Rizal Abd Rahman ${ }^{6}$ \\ Mazliza Mohamad ${ }^{7}$ \\ Mohd Azhan Yahya ${ }^{8}$ \\ ${ }^{1}$ Associate Professor, Faculty of Law, Universiti Kebangsaan Malaysia; aazam@ukm.edu.my \\ ${ }^{2}$ Associate Professor, Faculty of Law, Universiti Kebangsaan Malaysia; nazura@ukm.edu.my \\ ${ }^{3}$ Lecturer, Faculty of Law, Universiti Kebangsaan Malaysia; hakimah@ukm.edu.my \\ 4 Lecturer, Faculty of Law, Universiti Kebangsaan Malaysia; wardatun@ukm.edu.my \\ ${ }^{5}$ Lecturer, Faculty of Law, Universiti Kebangsaan Malaysia; rama@ukm.edu.my \\ ${ }^{6}$ Lecturer, Faculty of Law, Universiti Kebangsaan Malaysia; noryn@ukm.edu.my \\ 7 Lecturer, Faculty of Law, Universiti Kebangsaan Malaysia; mazliza@ukm.edu.my \\ ${ }^{8}$ Lecturer, Faculty of Law, Universiti Kebangsaan Malaysia; mohdazhanyahya@ukm.edu.my
}

Doi:10.5901/mjss.2016.v7n3p224

\section{Abstract}

The LLB programme at the Faculty of Law, UKM offers a unique blend of the civil and syariah curriculums. Throughout the existence of the faculty, the intention of producing law graduates who are well-balanced in their civil and syariah practical knowledge has always been evident. It is thus pertinent for the Law Faculty of Universiti Kebangsaan Malaysia or UKM to revamp and revitalise the syariah courses of Islamic Law of Securities and Islamic Family Law. Such efforts of regeneration of curriculums of these courses are indeed in sync with the faculty's aim of striking a balance between theories and practices in its educational approach. Such a move, if made, can be regarded as being in line with the current development within the syariah legal fraternity. Hence, the curriculum revamps were actually carried out on the said two syariah courses. The curriculum revamp on the course of Islamic Law of Securities had seen the integration of the 'Contractual Document-Drafting Technique' as one of its teaching tools. Meanwhile, the curriculum of the course of Islamic Family Law was reformed so as to include the 'Legal Opinion Writing Method' as one of its teaching tools. This writing examines challenges faced by the teaching teams of these two syariah courses. This paper critically examines challenges faced by the teaching staff of the courses of Islamic Law of Securities and Islamic Family Law. The research is conducted on a qualitative design. All arguments and findings are based on methodologies of critical and content analysis, field interviews and observation for data verifications. In the process, suggestions on means of overcoming these challenges are also discussed.

Keywords: Islamic Law of Securities, Islamic Family Law, teaching tool, curriculum, Contractual Document-Drafting Technique, Legal Opinion Writing Technique

\section{Introduction}

The Faculty of Law at Universiti Kebangsaan Malaysia (herein after referred to as UKM) has always kept abreast with the current development in the syariah legal industry. In its noble effort of becoming one of the leading law schools in Malaysia, the faculty has consistently modified and improved the course contents of its civil law as well as syariah law 
courses (A. Haji, 2013).

Historically speaking, only few syariah courses were offered when the faculty was first established in 1984 . The syariah courses on offer for the first year were Introduction to Islamic Law and Islamic Civilisation and Nationhood. The course of Islamic Jurisprudence-Family, Succession and Commercial Transaction was next offered for the second year while Islamic Jurisprudence- Crime and the Administration of Law was offered for the third year. There was no syariah course on offer for the final year. Since then, syariah curriculum has undergone many developments and transformations. Several new syariah courses were introduced over the years in the faculty's effort to keep abreast with current developments in the syariah legal industry. Two of these new syariah courses which found their way into the syariah law curriculum at the faculty were Islamic Law of Securities and Islamic Family Law. While Islamic Securities Law was a totally new course, the course of Islamic Family Law was in existence from the beginning but was later developed into a single course. Positive developments for both courses have been rapid and encouraging until practical hands-on classes were incorporated recently into their curriculum. The purpose of such incorporations was of course to train and develop the students' practical skills in both courses (Ahmad, 2013).

Both syariah courses of Islamic Law of Securities and Islamic Family Law have undergone transformations as far as both curriculums were concerned. The revamping of these curriculums was carried out to ensure that the course contents were in tandem with the most recent syariah legal developments. This was also in line with the noble aim of the faculty which is to produce a well-balanced law graduates who are able to plunge into civil and syariah practice with the minimum of guidance (Yusro, 2013; Hakimah, 2014).

\section{Objectives and Research Methodologies}

This research carries the following objectives. First and foremost, it aims at scrutinizing the evolvement of syariah courses. It particularly examines the courses' contents of Islamic Law of Securities and Islamic Family Law. Moreover, the research also identifies the shortcomings in the current courses' contents of both subjects. Last but not least, this research suggests enhancements to the courses' contents of Islamic Law of Securities and Islamic Family Law. The curriculum revamp on the course of Islamic Law of Securities had seen the integration of the 'Contractual DocumentDrafting Technique' as one of its teaching tools. Meanwhile, the curriculum of the course of Islamic Family Law was reformed so as to include the 'Legal Opinion Writing Method' as one of its teaching tools.

Research methodologies are carefully chosen in the conduct of the study. The research relies on a qualitative. Research methodologies such as critical and content analysis, field interviews and observation are adopted for data verifications. The methodologies of content analysis are used in obtaining and processing data and information on the evolvement of the courses' contents of Islamic Law of Securities and Islamic Family Law at UKM's Faculty of Law. The methodology of critical analysis is adopted when all these data and information are critically examined. Field interviews are conducted on past and present students of Islamic Law of Securities and Islamic Family Law. Data are collected from these field works on past weaknesses of both courses and the extent of effectiveness of the current teaching techniques, namely the 'Contractual Document-Drafting Technique' presently incorporated in the course of Islamic Law of Securities and the 'Legal Opinion Writing Method' currently implemented in the course of Islamic Family Law. During the field study, the methodology of observation is also adopted in assessment of the effectiveness of both new teaching tools. In this process the implementations of both new teaching techniques are critically observed and assessed.

\section{The Course of Islamic Law of Securities at Faculty of Law, UKM: The Use of 'Contractual Document-Drafting Method' as a Tool for Teaching and Learning}

Islamic Law of Securities has been a part of the combined civil and syariah courses taught in the LLB programme at the Law Faculty of UKM. It has always been the aim of the faculty to produce lawyers and legal practitioners capable of engaging into both the civil as well as syariah practice (Faridah, 2014). It was then timely when the law faculty made the bold step of offering a course on Islamic Securities Law. Evidently the course was aimed at fulfilling the requirement of the rapid advancement of the Islamic finance industries in Malaysia. The evolution of Islamic finance in Malaysia has seen demands and rise of legal issues that have become more competitive and complex (Hakimah, 2014).

A review of the teaching of the Islamic Securities Law saw a crucial need for inclusion of contract drafting in its curriculum. The move was deemed necessary as there were positive developments in Malaysia's Islamic finance industry in the 90's and the trend continued into the new millennium. As a result, more and more Islamic transactions, particularly Islamic securities transactions, were entered into by contracting parties. This had no doubt resulted in the drafting of securities' contract in most syariah securities transactions (A. Haji, 2013). 
Hence, the faculty reacted by modifying and revamping the course content of the course of Islamic Law of Securities. The 'contractual document-drafting method' was thereafter incorporated as one of the teaching techniques. Besides the normal classes on principles of Islamic securities, the students were most conveniently exposed to practical classes on contractual document-drafting. These classes used a hands-on approach in forms of various contractual drafting exercises. Clearly the move was to ensure that the faculty graduates would be capable of drafting proper Islamic securities contract that fulfil the requirement and demands of Islamic finance industry in Malaysia (Hakimah, 2014).

\section{The Course of Islamic Family Law at Faculty of Law, UKM: Incorporating 'Legal Opinion Writing' Technique as a New Tool in Teaching and Learning}

Besides Islamic Law of Securities, Islamic Family Law is another syariah course which forms the LLB programme at the Law Faculty of UKM. The offering of this course has always been a proof of how close and relevant the law degree is to the syariah legal fraternity and to the Malaysian public in general. This is because syariah family matters form an extremely important part of the public's life whereby muslims make up some sixty percent of the country's total population (Hashim, 2015).

Indeed, the practices of Muslim family law in Malaysia have become more challenging than ever in recent times. There has been a significant increase in divorces, matrimonial property disputes and child custody cases. Such cases demand syariah legal practitioners who are able to provide proper syariah legal counsels both orally and in written form. The skill of giving oral as well as written counsel is vital as it plays a major and significant role in case solving at pre-trial stage (Yusro, 2013).

The Faculty of Law recognized the importance of sharpening its students' opinion construction skills. This had resulted in a swiftly review and adjustment to the course content of Islamic Family Law. In a prompt reaction, the 'legal opinion writing technique' was incorporated into its process of teaching and learning. Through this technique, students attended not only the normal classes on syariah family principles, but were simultaneously exposed to practical classes on legal opinion writing skills. In these classes, practical hands-on approach on various legal opinion techniques were adopted in training and honing the students' skills of giving legal advice in the form of well-constructed opinions on various syariah family issues (Shariff, 2015).

The above revamp on the curriculum of Islamic Family Law was to ensure that the faculty graduates would be capable of giving well-constructed advice on syariah family matters in pre-trial settlements. This is vital in the face of increasing divorce, matrimonial property and child custody cases among muslims in Malaysia. The incorporation of this new teaching method could very well enhance the training of students on how to provide sound, practical and effective advice through legal opinion writing and counsel (Hakimah, 2014).

\section{Revamping Curriculums of the Syariah Courses of Islamic Securities Law and Islamic Family Law: Problems and Findings}

A study was conducted with the view of scrutinizing implementations of curriculum revamps on the syariah courses of Islamic Law of Securities and Islamic Family Law. Among the objectives set for the study were:

1. to analyse the course contents of syariah courses of Islamic Securities Law and Islamic Family Law at UKM's Faculty of Law, and compare it with the current needs of the syariah legal industry.

2. to identify the lacuna in the course contents of both courses.

3. to suggest enhancement to the course contents so as to fulfil the current needs of the recent syariah practices.

A study was conducted whereby students of these two syariah courses were interviewed and requested to fill up questionnaires. Two batches of students were approached for these purposes. For the course of Islamic Law of Securities, students from the 2013/2014 session expressed that the incorporation of the 'contractual document-drafting method' into the course content was good, feeling that such method had increased their understanding on the subject. The subsequent batch of students from the 2014/2015 session also shared the same sentiment, observing that such exposure through such method actually helped them developed their contract-drafting skills (Hakimah, 2014).

The students from the 2013/2014 session gave their two thumbs up for the incorporation of the 'legal opinion writing method' into the course content of the course of Islamic Family Law. They felt that such method had increased their understanding on the several issues on Islamic Family Law. The next batch of students from the 2014/2015 session also liked the method and felt that their improved understanding on all issues pertaining to Islamic Family Law simultaneously helped them developed their skills to counsel and provide advice (Hashim, 2015; Yusro, 2013).

All of the above students who have been approached, however, gave their views on how these practical hands-on 
classes could be improved. For Islamic Securities Law, some suggested that there should be more variety in the drafting exercises as there were many types of contracts which could all be used as basis of the exercises. This, according to them, could add versatility in their skills. For the course of Islamic Family Law, some students suggested that the University's Legal Aid Clinic be used as part of their training ground in addition to the normal hands-on classes (Ahmad, 2013; Hakimah, 2014).

Even key players in the syariah industry were interviewed. Those who were involved in the Islamic banking and securities industries felt that the introduction and incorporation of the 'contractual document-drafting method' into the course content was timely, observing the fact that Malaysia has indeed become the harp for Islamic banking and securities industries in the Asian region. This has indeed turned the Malaysian market into a competitive one as commercial national and international companies were eager to jump into the Islamic market which consequentially resulted in the players in the industries, muslims and non-muslims, entering into various Islamic banking as well as Islamic securities contracts. The fact that Malaysia has hosted a few important international conferences and meetings on banking and securities, Islamic and conventional, further signifies the potential of international market, so to speak (Hakimah, 2014).

The research team also approached syariah court judges and syarie lawyers to obtain feedbacks on the "legal opinion writing method' incorporated into the syllabus of the course of Islamic Family Law. All of them were of the view that such method which was aimed at developing the students' oral and writing skills in giving sound and constructed legal advice on Islamic family issues could not have come at a better time. Due to a sharp increase in divorce, matrimonial property disputes and child custody cases, they were of the view that the industry desperately needed syariah legal practitioners who are able to provide well-constructed advice both orally and written. Such skills, according to them, were needed mostly in pre-trial settlement sessions (Yusro, 2013).

Based on these feedbacks, the study had identified problems in the above curriculum revamps. In the case of Islamic Law of Securities, a lacuna in the course content was detected. Although the content was theoretically comprehensive, aspects of contract drafting were not given enough emphasis and exposure. Syariah compliant contract drafting skills are crucial to enable graduates are capable to draft proper Islamic securities contract that fulfil the requirement and demands of Islamic Finance industries in Malaysia.

Findings revealed that the course content of Islamic Securities Law at the Faculty of law need to be enhanced by including elements of actual practices of Islamic Finance. The present content has not specifically focused on practical aspects and technicality of Islamic contract drafting. In view of the rapid development of Islamic Finance and growing legal complexity, the skills of syariah contract drafting are therefore highly needed (Hakimah, 2014).

Meanwhile, there was also a lacuna in the course content of Islamic Family law at the faculty. Although the course was comprehensive in terms of theoretical content, practical aspects of legal opinion writing are found wanting. There is a need for more emphasis on teaching legal opinion writing as practical skills to provide sound legal advice for resolving cases.

Findings revealed that the course content of Islamic Family Law does not currently emphasize on the practical skills and techniques of legal opinion writing for provision of legal advice and counselling. Given increasing cases of divorces, matrimonial claims and matrimonial properties disputes, legal counsels must be skilful in providing counsel in these matters. Written and oral counsel in these matters must be credible, practical and able to resolve these pressing issues (Yusro, 2013).

\section{Conclusion}

In conclusion, both the syariah courses of Islamic Securities Law and Islamic Family Law have come a long way. There was a time when the Law Faculty, UKM did not even offer Islamic Law of Securities as a course. This was the case scenario until the faculty decided to offer the said course a few years back. Meanwhile, Islamic Family Law has been part of the faculty's law curriculum ever since its establishment in 1984. However, the Islamic Family Law component offered was extremely limited as it was clustered together with other syariah components. However, the said course had gradually developed over the years until it become a sole component in a single subject. The positive and encouraging developments on both syariah courses eventually reached a new milestone with incorporations of 'contractual documentdrafting method' and the 'legal opinion writing method' into the course contents of the courses of Islamic Securities Law and Islamic Family Law respectively with the aim of honing practical skills in the students.

Indeed, there were no developments without hiccups. In fact, such shortcomings in implementation of any teaching and learning process could propel the teaching team to greater successes provided that all lessons are learnt. Having this in mind, a study was conducted to identify weaknesses in the process of teaching and learning of Islamic Securities Law 
and Islamic Family Law. With sincerity and transparency in mind, the team approached students and players in the syariah legal industries in order obtaining honest assessments on implementation of both new methods of teaching in both courses. The feedbacks and comments have been inspiring.

The study has identified some problems regarding the implementation of these practical methods. The course of Islamic Securities Law needs to put a balance emphasis on theoretical and practical aspects. Contract drafting course should be included to train students in the techniques of proper syariah-compliant contract drafting. Such teaching and learning approach is crucial to produce graduates capable to meet the needs of the Islamic Finance industries in Malaysia.

The course of Islamic Family Law, on the other hand, needs to emphasize on the theoretical and practical aspects as well. As such, legal opinion writing should also be included in the course content. This is to enable the graduates to possess the skills for writing legal opinion for resolving such cases. Deficiency in legal opinion writing skills is a handicap to both students and legal practitioners. It mars the legal process. Therefore, legal opinion writing should be included in the course content for it shall guide students to provide syariah legal counsel in both oral and verbal forms.

Should all these shortcoming are properly rectified, there is no reason why the faculty could not produce law graduates who are capable of fitting in well in the legal industry in Malaysia. Indeed the industry needs such skilful practitioners who are able to contribute to the legal world and the Malaysian society.

\section{References}

A. Haji B. (2013). Bachelor of Law Programme at Faculty of Law UKM: A curriculum Review. Retreat Programme. Cheringin Hill Resort, Janda Baik, Pahang, 2013.

Ahmad A. Mohd Shariff. (2013). Teaching and Learning of Syariah Evidence Course: A UKM's Law School Experience. International Conference on Teaching and Learning. Universiti Sains Islam Malaysia (USIM), Nilai, Negeri Sembilan. October 2013.

A. Hakimah A. Halim. (2014). Review of LL.B Curriculum at UKM's Faculty of Law: A Report on Syariah Courses Content Review. Workshop on Law Curriculum Review. Port Dickson, Negeri Sembilan. May 2014.

Faridah A. Jalil. (2014). Law Curriculum Review by Faculty of Law UKM: Proposed Amendments and Revamps. Workshop on Undergraduates Teaching and Learning. Glory Beach Resort, Port Dickson. 21st-24th February 2014.

F. Yusro Hashim. (2013). Teaching and Learning Islamic Family Law: The Experience of Faculty of Law UKM. International Conference on Teaching and Learning. Universiti Sains Islam Malaysia (USIM), Nilai, Negeri Sembilan. October 2013.

Haji Hashim, F. Y. (2015). Convention on Innovation in Teaching and Learning Islamic Family Law: The Experience of Faculty of Law UKM. Convention on Innovation in Teaching and Learning. Universiti Kebangsaan Malaysia, Bangi, Selangor. May 2015

Mohd Shariff, A. A. (2015). Convention on Innovation in Teaching and Learning Islamic Family Law: The Experience of Faculty of Law UKM. Convention on Innovation in Teaching and Learning. Universiti Kebangsaan Malaysia, Bangi, Selangor. May 2015 